\title{
Season, Transport Duration and Trailer Compartment Effects on Blood Stress Indicators in Pigs: Relationship to Environmental, Behavioral and Other Physiological Factors, and Pork Quality Traits
}

\author{
Roberta Sommavilla ${ }^{1,+, \ddagger}$, Luigi Faucitano ${ }^{1,+}{ }^{\dagger}$ Harold Gonyou ${ }^{2}$, Yolande Seddon ${ }^{2}$, \\ Renée Bergeron ${ }^{3}$, Tina Widowski ${ }^{3}$, Trever Crowe ${ }^{4}$, Laurie Connor ${ }^{5}$, \\ Marina Bergoli Scheeren ${ }^{1} \S$, Sébastien Goumon ${ }^{6}$ and Jennifer Brown ${ }^{2, *}$ \\ 1 Agriculture and Agri-Food Canada, Sherbrooke Research and Development Centre, \\ Sherbrooke, QC J1M 0C8, Canada; robertasommavilla@gmail.com (R.S.); \\ luigi.faucitano@arc.gc.ca (L.F.); marinabergoli@hotmail.com (M.B.S.) \\ 2 Prairie Swine Centre, Saskatoon, SK S7H 5N9, Canada; hgonyou@shaw.ca (H.G.); \\ yolande.seddon@usask.ca (Y.S.) \\ 3 Department of Animal Biosciences, University of Guelph, Guelph, ON N1G 2W1, Canada; \\ rbergero@uoguelph.ca (R.B.); twidowsk@uoguelph.ca (T.W.) \\ 4 Department of Mechanical Engineering, University of Saskatchewan, Saskatoon, SK S7N 5A2, Canada; \\ trever.crowe@usask.ca \\ 5 Department of Animal Science, University of Manitoba, Winnipeg, MB R3T 2N2, Canada; \\ laurie.connor@umanitoba.ca \\ 6 Department of Ethology, Institute of Animal Science, Pratelstvi 815, \\ 10400 Prague-Uhrineves, Czech Republic; goumon.sebastien@vuzv.cz \\ * Correspondence: jab651@mail.usask.ca; Tel.: +1-306-667-7442 \\ + These authors contributed equally. \\ $\ddagger \quad$ Present address: Laboratory of Animal Welfare, Universidade Federal do Paraná, Curitiba 80.210-150, Brazil \\ $\S$ Present address: 704-689, Rua Sete de Setembro, Ijuí 98.700-000, Brazil
}

Academic Editors: John J. McGlone and Anna K. Johnson

Received: 3 November 2016; Accepted: 1 February 2017; Published: 8 February 2017

Simple Summary: Factors, such as ambient conditions, travel duration and vehicle design/ compartment location have an impact on the welfare of pigs during transport, carcass bruises and meat quality. Based on this, we aimed to assess the effects of these factors on blood creatine kinase, lactate and cortisol concentrations in 384 pigs and assess their relationships with trailer temperature, and pigs' heart rate and gastrointestinal tract temperature, behavior, carcass damage scores and meat quality. Although increased blood cortisol and creatine-kinase levels appear to indicate a physical stress condition in transported pigs, the weak to moderate correlations with environmental and other animal welfare indicators suggest that blood stress parameters can only be used as a complementary measurement in the assessment of the pigs' response to transport stress.

Abstract: The objective of this study was to assess the effects of the season, travel duration and trailer compartment location on blood creatine-kinase (CK), lactate and cortisol concentrations in 384 pigs and assess their relationships with trailer temperature, heart rate and gastrointestinal tract temperature (GTT), behavior, carcass damage scores and meat quality. Blood CK was greater in pigs transported in summer $(p=0.02)$, after $18 \mathrm{~h}$ transportation $(p<0.001)$ and in pigs located in C4, $\mathrm{C} 5$ and C10 $(p=0.002)$. In winter, the concentration of blood lactate was higher $(p=0.04)$ in pigs transported for $6 \mathrm{~h}$ in C5. Pigs located in C10 showed higher $(p=0.01)$ concentration of cortisol than those transported for $18 \mathrm{~h}$ in $\mathrm{C} 4$ in summer. The highest correlations were between blood cortisol and GTT $(r=0.53 ; p<0.001)$, and between blood CK and GTT $(r=0.41 ; p<0.001)$, truck temperature $(r=0.42 ; p<0.001)$, and $\mathrm{pH}_{\mathrm{u}}$ in the longissimus muscle $(r=0.41 ; p<0.001)$. In conclusion, although 
increased blood cortisol and CK levels appear to indicate a physical stress condition in transported pigs, the weak to moderate correlations with environmental and other animal welfare indicators suggest that blood stress parameters can only be used as a complementary measurement in the assessment of the pigs' response to transport stress.

Keywords: behavior; blood parameters; body temperature; heart rate; meat quality; pigs; season; stress response; transport time

\section{Introduction}

Factors, such as ambient conditions, travel duration and vehicle design/compartment location have an impact on the welfare of pigs during transport, carcass bruises and meat quality [1,2]. Collecting blood at exsanguination is a common, non-invasive technique for the assessment of the pigs' physiological response to these factors. Research has showed increased exsanguination blood CK and lactate levels in winter and summer, respectively [3,4], and in warmer trailer compartments [5]. Glucose, lactate and hematocrit levels are reported to increase in pigs transported for long duration [6,7], and blood cortisol and lactate concentrations to be greater after short journeys [8]. However, these results arise from studies where the effects of season, travel duration and compartment location were assessed separately. To our knowledge, the combined effects of these factors on exsanguination blood parameters have not been studied in pigs. Overall, correlations between blood stress parameters and other physiological indices, such as body temperature, behavior and meat quality range from none to moderate [9-12]. Nevertheless, correlations between exsanguination blood parameters, ambient and truck microclimate measures, and other physiological and behavioral response indicators to transport stress have not been calculated in one single study to validate their efficiency as a transport stress monitoring tool.

The objective of this study was to assess the effects of the season, travel duration and truck compartment location on exsanguination blood parameters and calculate their correlations with internal truck temperature, heart rate and gastro-intestinal tract temperature, transport and post-transport behavior, carcass damage and meat quality.

\section{Materials and Methods}

All experimental procedures performed in this study were approved by the University of Saskatchewan's Animal Research and Ethics Board and adhered to the Canadian Council on Animal Care guidelines for humane animal use [13].

\subsection{Animals and Transport Procedures}

The data reported in this experiment were collected during a larger study, whose results related to ambient and truck microclimate conditions, pigs' gastrointestinal tract temperature, heart rate, behavior, carcass damage and meat quality have been reported in two companion papers $[14,15]$. Data reported in this paper were collected from the same animals described by Goumon et al. [14], and Scheeren et al. [15].

In the overall study, a total of 5040 crossbred market-weight pigs (barrows and gilts) of the same genetics (Large White $\times$ Landrace sows and Duroc boars) and fed the same diet during finishing were transported from two commercial finishing farms to a commercial slaughter plant in Manitoba during the summer (July) and winter (January to February). Pigs were randomly distributed among three transport duration treatments: $6 \mathrm{~h}, 12 \mathrm{~h}$, or $18 \mathrm{~h}$ in both seasons. Four replicates of each journey were conducted during each season over four weeks (total of 96 groups). The average ambient temperatures throughout the transport were $22.9 \pm 1.7^{\circ} \mathrm{C}\left(12.5\right.$ to $\left.40.1^{\circ} \mathrm{C}\right)$ in summer and $-14.3 \pm 1.7^{\circ} \mathrm{C}(-28.8$ to $1.9^{\circ} \mathrm{C}$ ) in winter. All trucks used were pot-belly types (tri-axle, natural ventilation, air suspension), 
transporting 210 pigs on three decks, distributed into 10 compartments (Figure 1). The side panels were open $100 \%$ in the summer and $10 \%$ in the winter. The truck was bedded with $10 \mathrm{bags}(20 \mathrm{~kg} / \mathrm{bag})$ of wood shavings in summer and 8 bags of shavings and 9 bags of straw $(20 \mathrm{~kg} / \mathrm{bag})$ in winter.

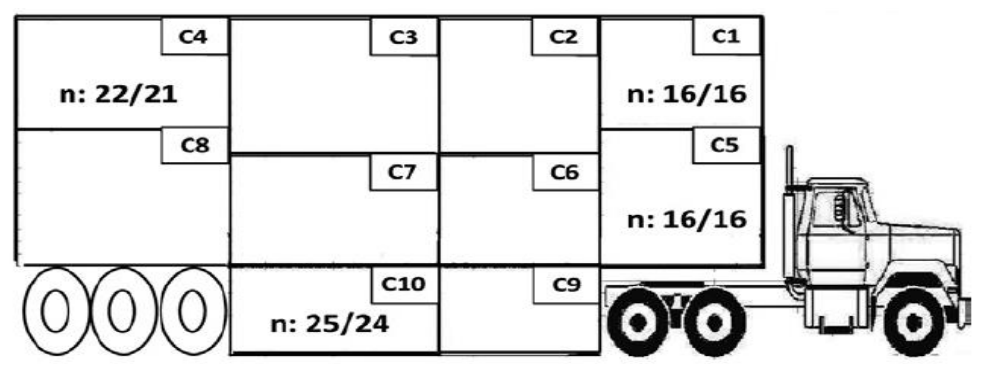

Figure 1. Compartment position inside the pot-belly trailer and distribution of pigs in the selected compartments in summer/winter.

A subsample of 384 sentinel pigs (128 per treatment, 16 barrows/trailer; body weight: $120.8 \pm 0.4 \mathrm{~kg}$ ) was randomly selected for the physiological study, including blood analysis, and meat quality assessment. Sentinel pigs were transported in 4 compartments (4 pigs/compartment), namely top front (C1), top back (C4), middle front (C5), and rear bottom (C10; Figure 1), which were shown to be the most detrimental locations to animal welfare and meat quality in previous studies using the same trailer model $[3,16]$.

Pigs transported for $18 \mathrm{~h}$ were off feed for approximately $24 \mathrm{~h}$ before slaughter, whereas those transported for 6 and $12 \mathrm{~h}$ were off for approximately $20 \mathrm{~h}$. Loads travelling to slaughter for 18, 12, and $6 \mathrm{~h}$ left the farm at respectively 1300, 1900, and $0100 \mathrm{~h}$. Each load consisted of unmixed pigs from the same farm and transported on the same truck. The different loads were transported by three different drivers, who were randomly assigned to transport duration treatments each week. The average space allowance on the truck was $0.37 \mathrm{~m}^{2} / 100 \mathrm{~kg}$ in summer and $0.38 \mathrm{~m}^{2} / 100 \mathrm{~kg}$ in winter. Throughout the loading procedure, pigs were handled by barn staff and drivers using plastic boards. Drivers and barn staff used electric prods under exceptional circumstances, such as moving reluctant pigs. The different loads arrived at the slaughter facility and were unloaded at $30 \mathrm{~min}$ intervals in a random, predetermined order beginning at $0630 \mathrm{~h}$. Pigs were unloaded from their respective compartments in the reverse order of loading and staff only used paddles (not prods). Pigs from $\mathrm{C} 1$ and $\mathrm{C} 4$ and from C5 and C10 were grouped $(n=38-41)$ at unloading and moved to holding pens in lairage, with space allowance of 1.1-1.2 $\mathrm{m}^{2} / \mathrm{pig}$. Pigs were provided ad libitum access to water in long troughs and held in lairage for $\sim 150 \mathrm{~min}$. After lairage, pigs were driven in a single file to the slaughter point, electrically stunned (head-to-chest stunning) and exsanguinated in the prone position.

\subsection{Blood Metabolites}

Blood samples were collected at exsanguination for the analysis of creatine kinase (CK), cortisol and lactate. Other sampling times were not possible due to concerns regarding interference with normal abattoir procedures and the additional stress this would impose on live pigs. At exsanguination, $10 \mathrm{~mL}$ of blood were collected from the 384 sentinel pigs in a tube (BD Vacutainers, VWR International Ltd., Montreal, QC, Canada) to extract serum for CK and cortisol. Serum samples were kept at room temperature $\left(\sim 23{ }^{\circ} \mathrm{C}\right)$ for $1 \mathrm{~h}$ before refrigeration at $4{ }^{\circ} \mathrm{C}$. The following day, serum samples were centrifuged at $4{ }^{\circ} \mathrm{C}$ for $12 \mathrm{~min}$ at $1400 \times \mathrm{g}$, transferred to $1.5 \mathrm{~mL}$ Eppendorf tubes, and stored at $-80^{\circ} \mathrm{C}$ until analysis. For the lactate analysis, another $2 \mathrm{~mL}$ of blood were collected in a tube containing $3.0 \mathrm{mg}$ of sodium fluoride and $6.0 \mathrm{mg}$ of $\mathrm{Na}_{2}$ EDTA solution and were immediately centrifuged at $4{ }^{\circ} \mathrm{C}$ for $12 \mathrm{~min}$ at $1400 \times \mathrm{g}$. Plasma was transferred into $1.5 \mathrm{~mL}$ Eppendorf tubes and stored at $-80^{\circ} \mathrm{C}$ until lactate determination. CK levels were measured using a commercial kit (Creatine Kinase-SL, Sukisui Diagnostics, Charlottetown, PE, Canada) and serum CK concentrations were determined with 
a spectrophotometer. The quantitative determination of serum cortisol was made using a commercial Elisa kit (Neogen Corp., Lexington, KY, USA) with a microplate reader and expressed as $\mathrm{ng} / \mathrm{mL}$. Lactate levels were measured using Lactate Assay Kit (Biomedical Research Service Center, University of Buffalo, Buffalo, NY, USA) and plasma lactate concentrations were determined with a microplate. The intra-assay CV was $4.61 \%, 3.21 \%$ and $3.98 \%$ for plasma lactate, serum CK and cortisol, respectively.

\subsection{Other Physiological Measures}

\subsubsection{Heart Rate}

Heart rate was recorded using Polar ${ }^{\circledR}$ heart rate monitors (Team Polar, Polar Electro Canada Inc., Quebec, QC, Canada) at 5-s intervals from loading to unloading and it was applied $4 \mathrm{~h}$ before loading, fitted around the pig's chest. The belts and monitors were removed immediately after unloading in order to avoid further interference with handling operations within the abattoir.

\subsubsection{Gastrointestinal Tract Temperature}

Gastrointestinal tract temperature (GTT) was monitored every minute from loading to lairage using iButton data. For administration, each pig was snared and a heavy gauge metal "pig gag" was inserted between its jaws to hold them open. A balling gun was used to insert the data logger into the pig's mouth, and the pig was released and monitored for $30 \mathrm{~s}$ to ensure that the logger had been swallowed. After slaughter, the viscera were removed from the processing line, and the loggers were recovered from the viscera by gross dissection. A temperature drop of more than $2{ }^{\circ} \mathrm{C}$ between recordings during lairage was considered indicative of drinking, and data after this time point were excluded from calculations.

\subsection{Behavioral Observations}

\subsubsection{On-Truck Behavior}

During transportation, behavior was recorded using digital cameras (Pentax Optio W90 12.1 MP, Mississauga, ON, Canada) mounted on the side of 3 of the compartments of interest (C1, C4 and C5) and programmed to take pictures at 5-min intervals. The cameras were mounted in such a way as to maximize the view of the compartments. No cameras were installed in C10 due to the lower height of the compartment. The percentages of animals within view that were standing, sitting or lying was recorded from the departure until the arrival at the slaughterhouse.

\subsubsection{Lairage Behavior}

Behavior during lairage was recorded by direct observation for $90 \mathrm{~min}$ beginning when the pigs entered the pen. Scan sampling was used at 5-min intervals to determine the number of pigs sitting, lying and drinking. The latency to rest was also determined as the time to when at least $50 \%$ of the pigs were lying.

\subsection{Truck Microclimate Measures}

One data logger (High Resolution Thermochron iButton DS1921H, Maxim Integrated Products, Inc., Sunnyvale, CA, USA) was mounted on the ceiling of each selected compartment in a central location to provide information about the temperature and relative humidity inside the compartments. The loggers were programmed to collect data at 5-min intervals throughout transport.

\subsection{Carcass Damage and Meat Quality Measurements}

Skin damage was assessed by the same trained technician on the day of slaughter in the cooler using the 5-point photographic scale $(1=$ none to 5 = severe; [17] $)$. 
Meat quality measurements were taken at $24 \mathrm{~h}$ post-mortem in the Longissimus (LM), Semimembranosus (SM) and Adductor (AD) muscles. Muscle ultimate $\mathrm{pH}\left(\mathrm{pH}_{\mathrm{u}}\right)$ was assessed using a pH meter (Oakton Instruments Model pH 100 Series, Nilis, IL, USA) by inserting the glass probe into LM, SM and AD muscles. Instrumental color ( $\mathrm{L}^{*}, \mathrm{a}^{*}$, and $\mathrm{b}^{*}$ values) was measured in the $\mathrm{LM}$ and SM muscles with a Minolta Chromameter (CR-300; Minolta Canada Inc., Mississauga, ON, Canada) equipped with a 25-mm aperture, $0^{\circ}$ viewing angle and D65 illuminant, after exposing the muscle surface to a 45-min blooming time. Drip loss was measured in the LM and SM muscles using the modified EZ-drip loss method as described by Correa et al. [18].

\subsection{Statistical Analyses}

Blood and ambient temperature statistical analyses were done using the MIXED procedure in SAS (v9.2, SAS, 2010, Cary, NC, USA [19]), with fixed effects of season, transport duration and trailer compartment, and their 2 and 3-way interactions. Weeks were used as random effect. Blood CK concentrations were log-transformed to achieve normality. Pearson correlations were calculated between blood data and meat quality traits. Spearman correlations were calculated between blood data and truck microclimate measures, behavior observations and physiological measures. A probability level of $p<0.05$ was chosen as the limit for statistical significance in all tests.

\section{Results}

\subsection{Blood Parameters}

As shown in Table 1, serum CK concentration was greater in summer $(p=0.03)$, after $18 \mathrm{~h}$ transportation $(p<0.001)$ and in pigs transported in C4 and C10 $(p<0.05)$. There was no interaction between season, duration and compartment for this blood variable.

The interaction season $x$ travel duration $x$ compartment location influenced plasma lactate and serum cortisol concentrations in this study, with lactate levels being higher $(p<0.05)$ in pigs transported for $6 \mathrm{~h}$ in $\mathrm{C} 5$ in winter (Figure 2) and cortisol values being higher $(p=0.01)$ in pigs transported in C10 compared with those located in $\mathrm{C} 4$ in the 18-h journey in summer (Figure 3).

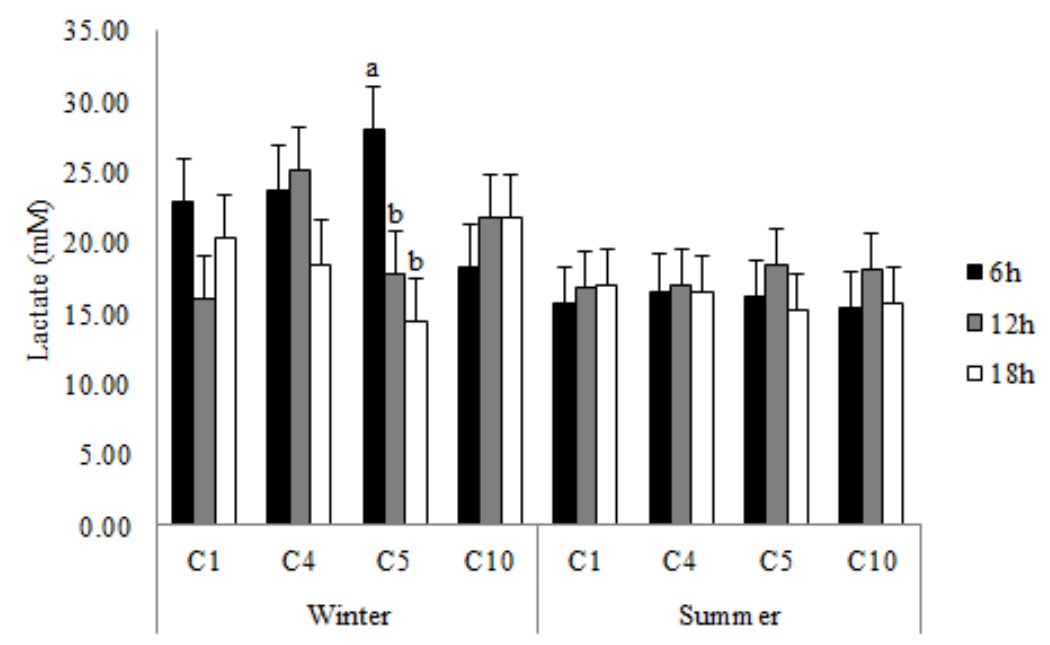

Figure 2. Blood lactate concentrations (LSM \pm SEM) in pigs transported for 6,12 and $18 \mathrm{~h}$ in the compartments $\mathrm{C} 1, \mathrm{C} 4, \mathrm{C} 5$ and $\mathrm{C} 10$ during winter and summer. ${ }^{\mathrm{a}, \mathrm{b}}$ Least squares means without a common superscript differ $(p<0.05)$. 
Table 1. Variation in blood lactate, creatine kinase (CK) and cortisol concentrations by season (winter and summer), travel duration (6, 12 and $18 \mathrm{~h})$ and trailer compartment location (C1, C4, C5 and C10).

\begin{tabular}{|c|c|c|c|c|c|c|c|c|c|c|c|c|c|c|}
\hline \multirow[b]{2}{*}{$n$} & \multicolumn{3}{|c|}{ Season (S) } & \multicolumn{4}{|c|}{ Duration (D) } & \multicolumn{4}{|c|}{ Compartment (C) } & \multicolumn{3}{|c|}{$p$ Value } \\
\hline & $\begin{array}{l}\text { Winter } \\
48\end{array}$ & $\begin{array}{l}\text { Summer } \\
48\end{array}$ & SEM & $\begin{array}{l}6 \mathrm{~h} \\
32\end{array}$ & $\begin{array}{c}12 \mathrm{~h} \\
32\end{array}$ & $\begin{array}{c}18 \mathrm{~h} \\
32\end{array}$ & SEM & $\begin{array}{l}\text { C4 } \\
24\end{array}$ & $\begin{array}{l}\text { C5 } \\
24\end{array}$ & $\begin{array}{l}\text { C10 } \\
24\end{array}$ & SEM & $\mathrm{S}$ & D & C \\
\hline $\mathrm{CK} *(\mathrm{U} / \mathrm{L})$ & $\begin{array}{c}2734^{\mathrm{b}} \\
(2054-3639)\end{array}$ & $\begin{array}{c}4424^{\mathrm{a}} \\
(3324-5888)\end{array}$ & & $\begin{array}{c}2720^{\mathrm{b}} \\
(2212-3343)\end{array}$ & $\begin{array}{c}3542^{\mathrm{a}} \\
(2881-4354)\end{array}$ & $\begin{array}{c}4367^{\mathrm{a}} \\
(3552-5368)\end{array}$ & & $\begin{array}{l}2612^{\mathrm{b}} \quad 4194^{\mathrm{a}} \\
(2087-3269)(3351-5248)\end{array}$ & $\begin{array}{c}3436^{\mathrm{a}, \mathrm{b}} \\
(2745-4300)\end{array}$ & $\begin{array}{c}3887^{\mathrm{a}} \\
(3106-3887)\end{array}$ & & 0.03 & $<0.001$ & 0.002 \\
\hline Lactate (mM) & 20.72 & 16.53 & 1.89 & 19.86 & 18.86 & 17.43 & 1.48 & 19.58 & 18.32 & 18.48 & 1.54 & 0.17 & 0.14 & 0.66 \\
\hline Cortisol (ng/mL) & $27.10^{b}$ & $36.60^{\mathrm{a}}$ & 2.06 & 32.28 & 32.32 & 30.95 & 1.67 & 31.43 & 32.37 & 33.04 & 1.77 & 0.02 & 0.55 & 0.47 \\
\hline
\end{tabular}

* The values in brackets are lower and upper values of $95 \%$ confidence interval. a,b Within a row, least squares means without a common superscript differ $(p<0.05)$. 


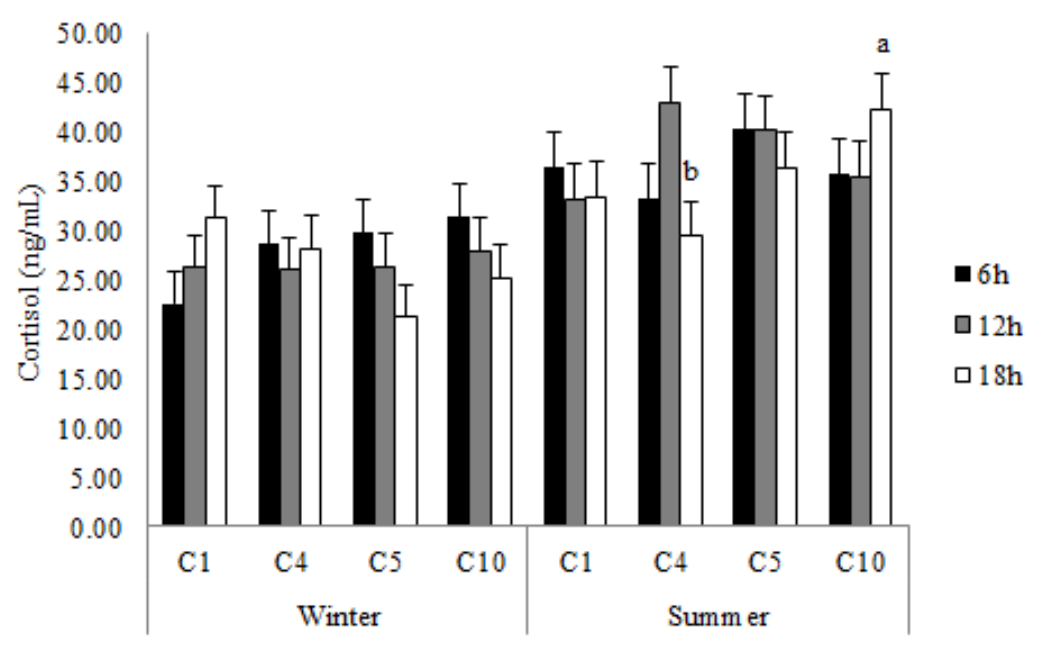

Figure 3. Blood cortisol value (LSM $\pm S E M$ ) in pigs transported for 6,12 and $18 \mathrm{~h}$ in the compartments $\mathrm{C} 1, \mathrm{C} 4, \mathrm{C} 5$ and $\mathrm{C} 10$ during winter and summer. ${ }^{\mathrm{a}, \mathrm{b}}$ Least squares means without a common superscript differ $(p<0.05)$.

\subsection{Trailer Compartment Temperature and Relative Humidity Variation by Season and Compartment}

In this study, during winter, the temperature was lower $(p<0.001)$ in the top compartments (C1 and $\mathrm{C} 4)$, while the temperature was higher $(p<0.001)$ in the bottom rear compartment $(\mathrm{C} 10)$ during summer (Table 2). Compartment RH was also higher $(p<0.001)$ in the top compartments (C1 and $\mathrm{C} 4)$ both in winter and summer.

Table 2. Least square means, SD, minimum and maximum values for temperature and relative humidity inside the selected trailer compartments $(\mathrm{C} 1, \mathrm{C} 4, \mathrm{C} 5$ and $\mathrm{C} 10)$ during winter and summer.

\begin{tabular}{|c|c|c|c|c|c|c|c|c|c|}
\hline \multirow{2}{*}{\multicolumn{2}{|c|}{ Season }} & \multicolumn{4}{|c|}{ Temperature $\left({ }^{\circ} \mathrm{C}\right)$} & \multicolumn{4}{|c|}{ Relative Humidity (\%) } \\
\hline & & $\mathrm{C} 1$ & $\mathrm{C} 4$ & C5 & C10 & $\mathrm{C} 1$ & $\mathrm{C} 4$ & C5 & C10 \\
\hline \multirow{4}{*}{ Winter } & Mean & $-0.9^{b}$ & $-1.6^{b}$ & $7.1^{\mathrm{a}}$ & $6.1^{\mathrm{a}}$ & $90.22^{a}$ & $92.29^{a}$ & $77.94^{\mathrm{b}}$ & $79.82^{b}$ \\
\hline & SD & 4.18 & 4.07 & 2.74 & 4.02 & 8.47 & 7.69 & 9.86 & 8.53 \\
\hline & Min. & -16.5 & -14 & -12.5 & -10.5 & 81.74 & 83.82 & 64.87 & 65.72 \\
\hline & Max. & 5.2 & 6.1 & 10.2 & 18.6 & 99.55 & 99.66 & 89.28 & 89.96 \\
\hline \multirow{4}{*}{ Summer } & Mean & $23.9^{b, c}$ & $23.1^{\mathrm{c}}$ & $24.7^{\mathrm{ab}}$ & $25.3^{\mathrm{a}}$ & $72.96^{\mathrm{a}}$ & $73.64^{a}$ & $68.04^{b}$ & $69.17^{b}$ \\
\hline & SD & 3.53 & 3.35 & 3.08 & 3.13 & 8.64 & 8.37 & 7.51 & 8.30 \\
\hline & Min. & 13.7 & 13.2 & 15.7 & 16.12 & 57.66 & 58.67 & 56.97 & 49.18 \\
\hline & Max. & 38.16 & 36.7 & 35.2 & 34.6 & 84.18 & 85.02 & 79.5 & 76.69 \\
\hline
\end{tabular}

No effect of transport time was found on compartment temperature values in this study $(p>0.05)$.

3.3. Correlations between Blood Parameters and Microclimate, Other Physiological, Behavior and Meat Quality Variables, and Carcass Damage Scores

Descriptive statistics for heart rate, gastrointestinal tract temperature (GTT), transport and lairage behavior and pork quality values, and carcass damage scores are shown in Table 3. 
Table 3. Descriptive statistics for heart rate, gastrointestinal tract temperature (GTT), transport and lairage behavior and pork quality values (as assessed in the longissimus, LM, semimembranosus, SM, and adductor, AD, muscles), and carcass damage scores.

\begin{tabular}{|c|c|c|c|c|}
\hline Parameter & Mean & SD & Minimum & Maximum \\
\hline Heart rate & 119.23 & 16.94 & 84.10 & 173.33 \\
\hline GTT $\left({ }^{\circ} \mathrm{C}\right)$ & 39.26 & 0.46 & 38.18 & 41.17 \\
\hline \multicolumn{5}{|l|}{ Transport behaviors } \\
\hline Standing $(\%)$ & 32.33 & 21.57 & 4.18 & 85.76 \\
\hline Sitting $(\%)$ & 17.74 & 6.92 & 1.05 & 33.19 \\
\hline Lying (\%) & 44.71 & 22.26 & 0 & 80.76 \\
\hline \multicolumn{5}{|l|}{ Lairage behaviors } \\
\hline Standing $(\%)$ & 2.20 & 1.91 & 0 & 10.37 \\
\hline Lying $(\%)$ & 73.14 & 9.98 & 43.33 & 96.11 \\
\hline Drinking (\%) & 2.93 & 2.09 & 0.20 & 8.94 \\
\hline Carcass damage score $^{1}$ & 1.77 & 0.40 & 1.00 & 3.50 \\
\hline \multicolumn{5}{|c|}{ Meat quality measurements } \\
\hline $\mathrm{LM} \mathrm{pH}_{\mathrm{u}}$ & 5.87 & 0.14 & 5.55 & 6.78 \\
\hline LM Minolta color $\mathrm{L}^{*}$ & 44.80 & 2.60 & 37.51 & 53.80 \\
\hline LM drip loss (\%) & 2.88 & 1.52 & -2.03 & 10.72 \\
\hline $\mathrm{SM} \mathrm{pH}_{\mathrm{u}}$ & 5.84 & 0.15 & 5.37 & 6.46 \\
\hline SM Minolta color L* & 43.77 & 3.18 & 34.10 & 51.61 \\
\hline SM drip loss (\%) & 3.23 & 1.42 & -2.71 & 7.08 \\
\hline $\mathrm{AD} \mathrm{pH}$ & 5.97 & 0.23 & 5.26 & 6.74 \\
\hline
\end{tabular}

Pearson correlation coefficients between blood parameters, heart rate, GTT, truck temperature, behavior, and meat quality characteristics are shown in Table 4.

Serum CK concentration was positively correlated with serum cortisol level $(r=0.45 ; p<0.001)$, carcass damage score $(r=0.29 ; p=0.003)$, heart rate $(r=0.23 ; p=0.02)$, GTT $(r=0.41 ; p<0.001)$, trailer temperature $(r=0.42 ; p<0.001)$ and $\mathrm{pH}_{\mathrm{u}}$ value in the $\mathrm{LM}(r=0.41 ; p<0.001)$. Whereas, negative correlations were found between serum CK level and trailer RH $(r=-0.36 ; p=0.003)$, drip loss value in the LM and SM muscle ( $r=-0.23 ; p=0.02$ and $r=-0.36 ; p<0.001$, respectively) and Minolta $\mathrm{L}^{*}$ value in both muscles ( $r=-0.38 ; p<0.001$ and $r=-0.25 ; p=0.01$, respectively).

Blood cortisol level was positively correlated with GTT $(r=0.31 ; p=0.002)$, trailer temperature $(r=0.53 ; p<0.001)$ and lying behavior during transport $(r=0.41 ; p=0.003)$. Whereas, it was negatively correlated with trailer RH $(r=-0.49 ; p<0.001)$ and standing behavior during transport $(r=-0.41$; $p=0.003)$.

Blood lactate concentration was negatively correlated with GTT $(r=-0.26 ; p=0.009)$, trailer temperature $(r=-0.38 ; p<0.001)$ and $\mathrm{pH}_{\mathrm{u}}$ value in the LM and SM muscle $(r=-0.25 ; p=0.02$ and $r=-0.32 ; p=0.002$, respectively). Whereas, it was positively correlated with trailer RH $(r=0.22$; $p=0.01)$ and Minolta $L^{*}$ value in the $\operatorname{LM}(r=0.21 ; p=0.04)$. 
Table 4. Correlations (Pearson, $r$ values) between blood parameters, heart rate, gastrointestinal tract temperature (GTT), trailer temperature ( $\mathrm{T}^{\circ}$ ) and relative humidity $(\mathrm{RH})$, transport and lairage behaviors, carcass damage score and meat quality characteristics as assessed in the longissimus (LM), semimembranosus (SM) and adductor (AD) muscles.

\begin{tabular}{|c|c|c|c|c|c|c|c|c|c|c|c|c|c|c|c|c|c|c|c|c|c|}
\hline \multicolumn{2}{|c|}{ Parameter } & \multirow[b]{2}{*}{ Cortisol } & \multirow[b]{2}{*}{ Lactate } & \multirow[b]{2}{*}{$\begin{array}{l}\text { Heart } \\
\text { Rate }\end{array}$} & \multirow[b]{2}{*}{ GTT } & \multirow[b]{2}{*}{$\begin{array}{l}\text { Standing } \\
\text { (Transport) }\end{array}$} & \multirow[b]{2}{*}{$\begin{array}{l}\text { Sitting } \\
\text { (Transport) }\end{array}$} & \multirow[b]{2}{*}{$\begin{array}{l}\text { Lying } \\
\text { (Transport) }\end{array}$} & \multirow[b]{2}{*}{$\begin{array}{l}\text { Standing } \\
\text { (Lairage) }\end{array}$} & \multirow[b]{2}{*}{$\begin{array}{l}\text { Lying } \\
\text { (Lairage) }\end{array}$} & \multirow[b]{2}{*}{$\begin{array}{l}\text { Drinking } \\
\text { (Lairage) }\end{array}$} & \multirow[b]{2}{*}{$\begin{array}{c}\text { Carcass } \\
\text { Damage } \\
\text { Score }\end{array}$} & \multirow[b]{2}{*}{$\begin{array}{c}\text { Compartment } \\
\mathrm{T}^{\circ}\end{array}$} & \multirow[b]{2}{*}{$\begin{array}{c}\text { Compartment } \\
\text { RH }\end{array}$} & \multirow[b]{2}{*}{$\mathrm{LM} \mathrm{pH}_{\mathrm{u}}$} & \multirow[b]{2}{*}{$\begin{array}{l}\text { LM } \\
\text { Minolta } \\
\text { Color L }\end{array}$} & \multirow[b]{2}{*}{$\begin{array}{l}\text { LM Drip } \\
\text { Loss }\end{array}$} & \multirow[b]{2}{*}{$\mathrm{SM} \mathrm{pH}_{\mathrm{u}}$} & \multirow[b]{2}{*}{$\begin{array}{l}\text { SM } \\
\text { Minolta } \\
\text { Color L* }\end{array}$} & \multirow[b]{2}{*}{$\begin{array}{l}\text { SM } \\
\text { Drip } \\
\text { Loss }\end{array}$} & \multirow[b]{2}{*}{$\begin{array}{l}\mathrm{AD} \\
\mathrm{pH}_{\mathrm{u}}\end{array}$} \\
\hline$\frac{r}{p}$ & CK & & & & & & & & & & & & & & & & & & & & \\
\hline$n^{1}$ & 96 & 96 & 96 & 95 & 96 & 48 & 48 & 48 & 96 & 96 & 96 & 96 & 88 & 88 & 84 & 96 & 96 & 84 & 94 & 94 & 84 \\
\hline $\mathrm{CK}^{2}$ & $\begin{array}{l}1 \\
-\end{array}$ & $\begin{array}{c}0.45 \\
<0.001\end{array}$ & $\begin{array}{c}-0.06 \\
0.57\end{array}$ & $\begin{array}{l}0.23 \\
0.02\end{array}$ & $\begin{array}{l}0.41 \\
<0.001\end{array}$ & $\begin{array}{c}-0.08 \\
0.56\end{array}$ & 0.11 & $\begin{array}{l}0.02 \\
0.89\end{array}$ & $\begin{array}{c}-0.15 \\
0.13\end{array}$ & $\begin{array}{c}-0.19 \\
0.06\end{array}$ & 0.65 & $\begin{array}{c}0.29 \\
0.003\end{array}$ & $\begin{array}{c}0.42 \\
<0.001\end{array}$ & $\begin{array}{l}-0.36 \\
0.003\end{array}$ & 0.0001 & $\begin{array}{c}-0.38 \\
0.0001\end{array}$ & $\begin{array}{c}-0.23 \\
0.02\end{array}$ & $\begin{array}{l}0.08 \\
0.48\end{array}$ & $\begin{array}{c}-0.25 \\
0.01\end{array}$ & $\begin{array}{l}-0.36 \\
<0.001\end{array}$ & $\begin{array}{c}0.013 \\
0.9\end{array}$ \\
\hline \multirow{2}{*}{\multicolumn{2}{|c|}{ Cortisol }} & 1 & 0.0 & 0.08 & 0.31 & -0.41 & 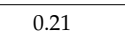 & 0.41 & -0.08 & -0.07 & -0.01 & 0.07 & 0.53 & -0.49 & -0.08 & -0.04 & 0.08 & -0.15 & 0.06 & 0.12 & $\overline{-0.12}$ \\
\hline & & - & 0.69 & 0.44 & 0.002 & 0.003 & 0.15 & 0.003 & 0.46 & 0.47 & 0.9 & 0.46 & $<0.001$ & $<0.001$ & 0.44 & 0.73 & 0.41 & 0.17 & 0.54 & 0.23 & 0.27 \\
\hline \multirow{2}{*}{\multicolumn{2}{|c|}{ Lactate }} & & 1 & -0.01 & -0.26 & -0.12 & -0.01 & 0 & 0.8 & 0 & -0.14 & 0 & -0.38 & 0.22 & -0.25 & 0.2 & 0.0 & -0.32 & 0.2 & -0.08 & 0.13 \\
\hline & & & - & 0.91 & 0.009 & 0.43 & 0.95 & 0.43 & 0.68 & 0.48 & 0.16 & 0.61 & $<0.001$ & 0.01 & 0.02 & 0.04 & 0.9 & 0.002 & 0.01 & 0.42 & 0.24 \\
\hline
\end{tabular}

${ }^{1} n$ : Unit was trailer compartment. For postures during transport $(n=48)$ two compartments were analysed per trailer, and the values were correlated against the corresponding blood and meat quality values for trailer compartment. ${ }^{2} \mathrm{CK}$ : creatine kinase. 


\section{Discussion}

\subsection{Blood CK Variation}

In this study, a significant effect of season was found for blood CK, with higher levels in summer, suggesting that heat stress played a significant role as shown by the significant, although moderate, positive correlations between this blood variable and pigs' GTT and trailer internal temperature. Blood CK levels in this study rose significantly with increasing transport time, unlike the study by Chai et al. [20] which found no effect of transport times of $40 \mathrm{~min}, 3 \mathrm{~h}$ and $5 \mathrm{~h}$ on CK. This result is likely due to the much longer transport durations and more extreme temperature conditions examined in the current study. CK levels increase gradually in response to muscle exertion or damage, with peak levels found $6 \mathrm{~h}$ following injury [21]. This study also found compartment differences in CK, in contrast to the study by Correa et al. [4], which found no effect of location within the trailer on serum CK concentrations. Blood CK levels were generally higher in rear compartments (C4, C10) than in front (C1, C5), whereas Correa et al. [4] compared deck levels. The correlations of blood CK with muscle $\mathrm{pHu}$ and drip loss and colour lightness values confirm the role of this blood metabolite as a potential indicator of physical fatigue and muscle glycogen exhaustion, resulting in pork with DFD characteristics [3].

\subsection{Blood Cortisol Variation}

Blood cortisol concentrations were also influenced by the interaction season $\mathrm{x}$ transport time $\mathrm{x}$ compartment location in this study, with greater levels being found in summer, after $18 \mathrm{~h}$ travel time and in pigs located in the bottom rear compartment (C10). Based on the positive correlations with trailer temperature, which was greater in C10, pigs' GTT and lying behavior during transport, the blood cortisol level increase may be interpreted as a response to heat stress which made pigs lie down more during transport as reported in the companion study by Goumon et al. [14]. Increased lying behavior is observed in pigs under warm ambient conditions with the objective of increasing the functional surface area for heat loss [22,23]. Greater cortisol concentrations after longer transport times ( $5 \mathrm{~h}$ vs. $40 \mathrm{~min}$ ) have been also reported by Chai et al. [20] and may result from the additive effect of the $4 \mathrm{~h}$ longer feed withdrawal due to increasing demand for energy supply in these pigs [24].

\subsection{Blood Lactate Variation}

In previous research, lactate levels have been found to increase rapidly in response to acute stress, with a response time of $4 \mathrm{~min}$ [25]. In the current study, blood lactate increased in pigs transported in winter, but season effects were aggravated by the combined effects of shorter transport time and compartment location. The correlation between increased blood lactate level and decreased trailer temperature and GTT may explain the effects of winter on this blood variable in response to cold stress in this study. Greater lactate concentrations in exsanguination blood from pigs transported for a short time were also reported by Pérez et al. [8]. The effects of low temperatures and shorter travel time were accentuated in pigs located in the middle front compartment (C5) despite the fact that this compartment was the warmest during the winter trials in this study. Other studies found higher blood lactate concentrations during winter $[4,26,27]$ and correlated with the longer latency to lie down in lairage and delayed recovery from transport in this season [4]. However, this interpretation cannot be applied for the results of this study as no significant correlation was found between blood lactate level at exsanguination and standing/lying behavior in lairage. Similarly to a number of studies [3,10-12], blood lactate increase contributed, although weakly, with post-mortem meat acidification resulting in paler pork.

\section{Conclusions}

The results of this study suggest that pigs transported at elevated truck temperatures are likely to experience higher stress showed by the increase of blood cortisol and CK levels, combined with 
higher frequencies of lying during transport and drinking in lairage. These effects are exacerbated by the position of the animal in the trailer during transportation, meaning that the design of vehicles used for swine transportation in Canada should be improved to ensure more consistent comfort for all animals, regardless of their position in the truck, during travel. However, based on the weak to moderate correlations with environmental, other physiological and behavior indicators and meat quality traits, the stress parameters measured in blood collected at exsanguination in this study cannot be considered other than as a complementary measurement in the assessment of the physiological response to transport stress.

Acknowledgments: The authors acknowledge with gratitude the financial support of Sask Pork, Alberta Pork, Manitoba Pork, Ontario Pork, Maple Leaf Foods, the Alberta Livestock Meat Agency, the Saskatchewan Agricultural Development Fund and the Natural Sciences and Engineering Research Council. The authors also wish to acknowledge the technical assistance of Sophie Horth, Fiona Rioca-Lang, Megan Bouvier, Brenda Sawatsky and Angela Vanelli Weschenfelder. Special thanks go to Steve Méthot for his help with the statistical analysis. The project was made possible by the cooperation of participating producers and Maple Leaf Foods. Sébastien Goumon was supported by Grant No. MZERO0716 from the Czech Ministry of Agriculture.

Author Contributions: Conceived and design the experiments: René Bergeron, Trever Crowe, Harold Gonyou, Tina Widowski; obtained the financial support: René Bergeron, Trever Crowe, Harold Gonyou, Tina Widowski; prepared pigs at the farm: Jennifer Brown, Sebastien Goumon, Marina Bergoli Scheeren, Tina Widowski and Harold Gonyou; performed the physiological data collection and analysis: Jennifer Brown, Sebastien Goumon, René Bergeron, Trever Crowe, and Marina Bergoli Scheeren; performed the carcass and meat quality data collection and analysis: Jennifer Brown, Sebastien Goumon, Laurie Connor and Marina Bergoli Scheeren; performed the statistical analysis: Roberta Sommavilla and Yolande Seddon; wrote the paper: Roberta Sommavilla, Luigi Faucitano, Jennifer Brown.

Conflicts of Interest: The authors declare no conflict of interest.

\section{References}

1. Schwartzkopf-Genswein, K.S.; Faucitano, L.; Dadgar, S.; Shand, P.; González, L.A.; Crowe, T.G. Road transport of cattle, swine and poultry in North America and its impact on animal welfare, carcass and meat quality: A review. Meat Sci. 2012, 92, 227-243. [CrossRef] [PubMed]

2. Conte, S.; Faucitano, L.; Bergeron, R.; Torrey, H.V.; Gonyou, H.W.; Crowe, T.; Tamminga, E.T.; Widwoski, T.M. Effects of season, truck type, and location within truck on gastrointestinal tract temperature of market-weight pigs during transport. J. Anim. Sci. 2015, 93, 5840-5848. [CrossRef] [PubMed]

3. Correa, J.A.; Gonyou, H.W.; Torrey, S.; Widowski, T.; Bergeron, R.; Crowe, T.G.; Laforest, J.P.; Faucitano, L. Welfare and carcass and meat quality of pigs being transported for two hours using two vehicle types during two seasons of the year. Can. J. Anim. Sci. 2013, 93, 43-55. [CrossRef]

4. Correa, J.A.; Gonyou, H.W.; Torrey, S.; Widowski, T.; Bergeron, R.; Crowe, T.; Laforest, J.P.; Faucitano, L. Welfare of pigs being transported over long distances using a pot-belly trailer during winter and summer. Animals 2014, 4, 200-213. [CrossRef] [PubMed]

5. Fox, J.; Widowski, T.; Torrey, S.; Nannoni, E.; Bergeron, R.; Gonyou, H.W.; Brown, J.A.; Crowe, T.; Mainau, E.; Faucitano, L. Water sprinkling market pigs in a stationary trailer. 1. Effects on pig behaviour, gastrointestinal tract temperature and trailer micro-climate. Livest. Sci. 2014, 160, 113-123. [CrossRef]

6. Mota-Rojas, D.; Becerril, M.; Lemus, C.; Sanchez, P.; Gonzalez, M.; Olmos, S.A.; Ramirez, R.; Alonso-Spilsbury, M. Effects of mid-summer transport duration on pre- and post-slaughter performance and pork quality in Mexico. Meat Sci. 2006, 73, 404-412. [CrossRef] [PubMed]

7. Becerril-Herrera, M.; Alonso-Spilsbury, M.; Ortega, M.E.; Guerrero-Legarreta, I.; Ramirez-Necoechea, R.; Roldan-Santiago, P.; Perez-Sato, M.; Soni-Guillermo, E.; Mota-Rojas, D. Changes in blood constituents of swine transported for 8 or $16 \mathrm{~h}$ to an abattoir. Meat Sci. 2010, 86, 945-948. [CrossRef] [PubMed]

8. Pérez, M.P.; Palacio, J.; Santolaria, M.P.; Aceña, M.C.; Chacón, G.; Gascón, M.; Calvo, J.H.; Zaragoza, P.; Beltran, J.A.; Garcia-Belenguer, S. Effect of transport time on welfare and meat quality in pigs. Meat Sci. 2002, 61, 425-433. [CrossRef]

9. Warriss, P.D.; Pope, S.J.; Brown, S.N.; Wilkins, L.J.; Knowles, T.G. Estimating the body temperature of groups of pigs by thermal imaging. Vet. Rec. 2006, 158, 331-334. [CrossRef] [PubMed] 
10. Edwards, L.N.; Engle, T.E.; Correa, J.A.; Paradis, M.A.; Grandin, T.; Anderson, D.B. The relationship between exsanguination blood lactate concentration and carcass quality in slaughter pigs. Meat Sci. 2010, 85, 435-440. [CrossRef] [PubMed]

11. Weschenfelder, A.V.; Saucier, L.; Maldague, X.; Rocha, L.M.; Schaefer, A.L.; Faucitano, L. Use of infrared ocular thermography to assess physiological conditions of pigs prior to slaughter and predict pork quality variation. Meat Sci. 2013, 95, 616-620. [CrossRef] [PubMed]

12. Rocha, L.M.; Dionne, A.; Saucier, L.; Nannoni, E.; Faucitano, L. Hand-held lactate analyzer as a tool for the real-time measurement of physical fatigue before slaughter and pork quality prediction. Animal 2015, 9, 707-714. [CrossRef] [PubMed]

13. Canadian Council on Animal Care. Guidelines on the Care and Use of Farm Animals in Research, Teaching and Testing; Canadian Council on Animal Care: Ottawa, ON, Canada, 2009; p. 162.

14. Goumon, S.; Brown, J.A.; Faucitano, L.; Bergeron, R.; Widowski, T.M.; Crowe, T.; Connor, M.L.; Gonyou, H.W. Effects of transport duration on maintenance behavior, heart rate and gastrointestinal tract temperature of market-weight pigs in 2 seasons. J. Anim. Sci. 2013, 91, 4925-4935. [CrossRef] [PubMed]

15. Scheeren, M.B.; Gonyou, H.W.; Brown, J.; Weschenfelder, A.V.; Faucitano, L. Effects of transport time and location within truck on skin bruises and meat quality of market weight pigs in two seasons. Can. J. Anim. Sci. 2014, 94, 71-78. [CrossRef]

16. Torrey, S.; Bergeron, R.; Faucitano, L.; Widowski, T.; Lewis, N.; Crowe, T.; Correa, J.A.; Brown, J.; Hayne, S.; Gonyou, H.W. Transportation of market-weight pigs II. Effect of season and location within truck on behavior with an 8-h transport. J. Anim. Sci. 2013, 91, 2872-2878. [CrossRef] [PubMed]

17. Meat and Livestock Commission. Rindside Damage Scale. Reference 2031M 8/85; Meat and Livestock Commission: Bletchley, UK, 1985.

18. Correa, J.A.; Methot, S.; Faucitano, L. A modified meat juice container (EZ-DripLoss) procedure for a more reliable assessment of drip loss and related quality changes in pork meat. J. Muscle Foods. 2007, 18, 67-77. [CrossRef]

19. SAS Statistical Analysis System. Release 9.4, 2002-2012; SAS Institute Inc.: Cary, NC, USA, 2013.

20. Chai, J.; Xiong, Q.; Zhang, C.X.; Miao, W.; Li, F.E.; Zheng, R.; Peng, J.; Jiang, S.W. Effect of pre-slaughter transport plant on blood constituents and meat quality in halothane genotype of NN Large White $\times$ Landrace pigs. Livest. Sci. 2010, 127, 211-217. [CrossRef]

21. Knowles, T.G.; Warriss, P.D. Stress physiology of animals during transport. In Livestock Handling and Transport; Grandin, T.A., Ed.; CAB International: Wallingford, UK, 2000; pp. 385-407.

22. Montieth, J.L.; Mount, L.E. Heat Loss from Animals and Man; Butterworths: London, UK, 1974.

23. Schmidt-Nielsen, K. P8 in Animal Physiology: Adaptation and Environment, 3rd ed.; Cambridge University Press: Cambridge, UK, 1983.

24. Von Mickwitz, G. Various transport conditions and their influence on physiological reactions. In Transport of Animals Intended for Breeding, Production and Slaughter; Moss, R., Ed.; Martinus Nijhof Publishers: Hague, The Netherlands, 1982; pp. 45-54.

25. Benjamin, M.E.; Gonyou, H.W.; Ivers, D.J.; Richardson, L.F.; Jones, D.J.; Wagner, J.R.; Seneriz, R.; Anderson, D.B. Effect of animal handling method on the incidence of stress response in market swine in a model system. J. Anim. Sci. 2001, 79 (Suppl. S1), 279.

26. Averós, X.; Knowles, T.G.; Brown, S.N.; Warriss, P.D.; Gosálvez, L.F. Factors affecting the mortality of pigs being transported to slaughter. Vet. Rec. 2008, 163, 386-390. [CrossRef] [PubMed]

27. Aradom, S.; Gebresenbet, G.; Bulitta, F.S.; Bobobee, E.Y.; Adam, M. Effect of transport times on welfare of pigs. J. Agric. Sci. Technol. A 2012, 2, 544-562.

(c) 2017 by the authors; licensee MDPI, Basel, Switzerland. This article is an open access article distributed under the terms and conditions of the Creative Commons Attribution (CC BY) license (http:/ / creativecommons.org/licenses/by/4.0/). 